Article

\title{
Improvement of BIPV Efficiency by Application of Highly Reflective Surfaces at the Building Envelope
}

\author{
Dominika Knera $^{1}\left(\mathbb{D}\right.$, Pablo Roberto Dellicompagni ${ }^{2}$ and Dariusz Heim ${ }^{1, *(D)}$ \\ 1 Department of Environmental Engineering, Lodz University of Technology, 90924 Lodz, Poland; \\ dominika.knera@p.lodz.pl \\ 2 Centro de Investigación y Desarrollo en Materiales Avanzados y Almacenamiento de Energía de \\ Jujuy (CIDMEJu), San Salvador de Jujuy 5707, Argentina; pablodellicompagni@cidmeju.unju.edu.ar \\ * Correspondence: dariusz.heim@p.lodz.pl
}

check for updates

Citation: Knera, D.; Dellicompagni, P.R.; Heim, D. Improvement of BIPV Efficiency by Application of Highly Reflective Surfaces at the Building Envelope. Energies 2021, 14, 7424. https://doi.org/10.3390/en14217424

Academic Editor:

Giovanni Pernigotto

Received: 11 October 2021

Accepted: 4 November 2021

Published: 8 November 2021

Publisher's Note: MDPI stays neutral with regard to jurisdictional claims in published maps and institutional affiliations.

Copyright: (c) 2021 by the authors. Licensee MDPI, Basel, Switzerland. This article is an open access article distributed under the terms and conditions of the Creative Commons Attribution (CC BY) license (https:// creativecommons.org/licenses/by/ $4.0 /)$.

\begin{abstract}
The use of concentrated solar irradiation for the improvement of electric generation improvement has been implemented on different scales, mainly in photovoltaic systems. Highconcentration Fresnel lenses are widely chosen for this approach in large installations, while lowconcentration systems are rather applied in medium-low scales. For the latter, the improvement on electric performance was revealed, even when no solar tracking was implemented. The presented work aims to analyse a low-concentration photovoltaic installation by a numerical approach. First, the reflective surfaces were designed geometrically considering the optimal slope determined for each month. Subsequently, different simulation techniques were used separately for prediction of solar irradiation and energy production. Three criteria were selected to analyze power generation: the highest increase in total annual solar irradiance on panels with reflective surfaces, the highest total annual solar irradiance collected, and the optimal slope of panels for the entire year. The increase in energy was found to not exceed $10 \%$ in the winter months. Whereas in the spring and summer months the energy improvement is about $15-20 \%$. Moreover, it was observed that the temperature of the proposed concentration photovoltaic system increased significantly, reaching more than $90{ }^{\circ} \mathrm{C}$, while for traditional PV panels it did not exceed $75^{\circ} \mathrm{C}$.
\end{abstract}

Keywords: solar radiation; low-concentration systems; ray tracing; Monte Carlo; one-diode PV model; CIGS

\section{Introduction}

Several efforts have been made to improve power generation in photovoltaic (PV) systems and their efficiency. The techniques applied to achieve this goal are diverse and can be divided into two main groups: methods to increase the amount of solar radiation incident into the panels (higher power generation) and methods to thermally stabilize the panels (higher efficiency). It can be found from the literature that the increase in solar radiation can be achieved by concentrating systems for PV (CPV) installations [1], mainly Fresnel lenses [2,3]. For large photovoltaic panels, a spectrum of Fresnel lenses is proposed in most cases [3,4]. As the sunrays are concentrated on a smaller surface, the temperature of PV cells under concentrated illumination increases [5] by means of a decrease in efficiency [6]; then cooling systems are necessary to avoid overheating [7]. There are some possibilities to cool the PV panels by combining them with thermal collectors (T-PV) [8], application of phase change materials (PCM) [9] or the removal of heat through a water channel [10]. In the case of building integrated photovoltaics (BIPV) [11], the increase in temperature can even increase the risk of PV damage or accelerate the ageing effect [12]. Some authors have proposed to use different techniques to cool BIPV, even using phase change materials on the back surface of the photovoltaic panel in rainscreen cladding [13] or composite systems [14]. Although Fresnel lenses are considered the most suitable method to increase the performance of photovoltaic installations $[15,16]$, the overheating problem 
is generally more common than in the case of free-standing or integrated PV building. Improving its thermal efficiency also increases the cost of installations and maintenance.

Diverse authors studied technological solutions for low-concentration ratios [16,17]. Low-concentration photovoltaic systems for large scale solar plants are also possible due to R\&D investments that the most well-known companies have been encouraging. Such as the Abengoa Solar case [16], which owns a 1.2 MW PV plant with flat mirror concentration systems on each single PV panel. This solar plant is in Sevilla, Spain; and it is composed of 154 operational units with a heliostat sun-tracking system. Abella et al. [18] designed a fourface polyhedral mirror that gave a concentration ratio of 3 compared to a single photovoltaic panel. The experimental setup consisted of a sun-tracking structure with 12 photovoltaic panels, each one with their mirrored system, and the electrical performance was studied both numerically and experimentally. Overheating protection was implemented by an aluminium heat sink. Both numerical and experimental results have shown that power output is almost 1.91 times compared with STC values, and the short-circuit current obtained was about 2.5 bigger than STC conditions. On the other hand, a fill factor decrease was caused by the combined effects of concentration and temperature. On a shorter scale, a similar analysis was carried out by Julajaturasirarath et al. [19], who modeled a single PV panel $(10 \mathrm{~W})$ in combination with flat mirrors surrounding it. An electrical and reflective numerical model was performed to obtain the energy production, and experimental comparisons were carried out during seven days of data collection. They found that the reflectivity of the mirror can provide more energy than traditional panels, about double the power output. Furthermore, a recent study [20] determined that it is also possible to obtain better electric power generation when both the PV panel and reflective flat surfaces are in a fixed position, without tracking the sun. The maximum output power of the solar panel is increased by using flat mirrors as concentrators and the variation in maximum power is $17 \%$, while the efficiency improvement can reach $25 \%$.

Regarding practical limitations (wind and snow) and possibly architectural integration (roof or façade), the PV system studied in this paper is considered rather as a building integrated one (BIPV). This assumption allows for the use of a building as a supporting structure for the whole system. Moreover, it helps in the general maintenance and cleaning of the reflected and PV surfaces. In modern architecture design, integration of PV panels is not the exceptional case [21]. In addition to aesthetic aspects [22] the proposed system should fully interact with other building elements [23]. Monteleone et al. proposed an adaptive envelope component, namely SLICE (Solar Lightweight Intelligent Component for Envelopes), equipped with high-efficiency photovoltaic cells, and which is a lightweight and stand-alone component for dynamic envelopes [24]. Double-wedge BPPL (Building Perma-Power Link) panels were proposed and analysed in the case of a mid-rise building in Seattle, Washington [25]. Each cladding panel was designed as a stand-alone system, which will be useful for installation, operation, and maintenance. Finally, the aluminium foil-based Bi reflector system (Al-BRS) was investigated, giving an improvement of output power more than $28.47 \%$ (in comparison with traditional BIPV) depending on the time, size of the reflector, and location of the solar panel [26].

The possible implementations of the proposed solution as a building integrated system are presented in Table 1. It should be depicted that all required components are available on the market and materials are common in architecture design. Seven different cases of façade and roof integrated systems were proposed and specified, but more cases can be further developed. It should be noted that the building structure operates as a supporting construction eliminating the mechanical problem due to the wind or snow loads. The general maintenance of building façades or roofs also help to keep the system in proper conditions. 
Table 1. Options for building integration of mirrored PV panels.

\begin{tabular}{|c|c|c|c|c|}
\hline & Scheme & Category & Mounting & Features \\
\hline 1 & & $\begin{array}{l}\text { Window } \\
\text { integrated }\end{array}$ & $\begin{array}{l}\text { Supportive } \\
\text { structure for } \\
\text { mirrors and } \\
\text { panels }\end{array}$ & $\begin{array}{l}\text { No tracking consumption } \\
\text { Saving energy for } \\
\text { lightning } \\
\text { Partial light guiding into } \\
\text { inside } \\
\text { Relatively low visual } \\
\text { impact }\end{array}$ \\
\hline 2 & & $\begin{array}{c}\text { Wall } \\
\text { integrated }\end{array}$ & $\begin{array}{l}\text { Directly on wall } \\
\text { Supportive } \\
\text { structure for } \\
\text { mirrors }\end{array}$ & $\begin{array}{l}\text { No tracking consumption } \\
\text { - Room aspect not affected } \\
\text { - Medium visual impact }\end{array}$ \\
\hline 3 & & $\begin{array}{l}\text { Door/ } \\
\text { /window } \\
\text { shading } \\
\text { elements }\end{array}$ & $\begin{array}{l}\text { Supportive } \\
\text { structure on the } \\
\text { wall }\end{array}$ & $\begin{array}{l}\text { No tracking consumption } \\
\text { Room overheating } \\
\text { avoided in summer } \\
\text { Room aspect not affected } \\
\text { - } \text { Low-medium visual } \\
\text { impact }\end{array}$ \\
\hline 4 & & $\begin{array}{c}\text { Balcony } \\
\text { integration }\end{array}$ & $\begin{array}{l}\text { Directly on } \\
\text { balcony façade } \\
\text { Supportive } \\
\text { structure for } \\
\text { mirrors }\end{array}$ & $\begin{array}{l}\text { No tracking consumption } \\
\text { Easy cleaning } \\
\text { 口 Additional shading } \\
\text { - Medium-high visual } \\
\text { impact }\end{array}$ \\
\hline 5 & & $\begin{array}{l}\text { Double skin } \\
\text { façade } \\
\text { integration }\end{array}$ & $\begin{array}{l}\text { Supportive } \\
\text { structure on the } \\
\text { wall/transparent } \\
\text { covering }\end{array}$ & $\begin{array}{l}\text { - No tracking consumption } \\
\text { No wind pressure when } \\
\text { inside } \\
\text { No PV panel overheating } \\
\text { when outside } \\
\text { Relatively low to medium } \\
\text { visual impact }\end{array}$ \\
\hline 6 & & $\begin{array}{l}\text { Sloped roof } \\
\text { integration }\end{array}$ & $\begin{array}{l}\text { Supportive } \\
\text { structure for } \\
\text { mirrors }\end{array}$ & 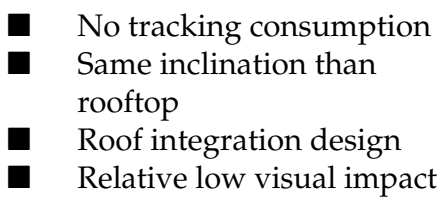 \\
\hline 7 & & $\begin{array}{c}\text { Flat roof } \\
\text { integration }\end{array}$ & $\begin{array}{l}\text { Supportive } \\
\text { structure for } \\
\text { mirrors and } \\
\text { panels }\end{array}$ & $\begin{array}{l}\text { Tracking system could be } \\
\text { incorporated } \\
\text { Low-medium visual } \\
\text { impact } \\
\text { Better harnessing of space } \\
\text { and modularization }\end{array}$ \\
\hline
\end{tabular}

The main aim of the presented study is to design a low-concentration photovoltaic system and to analyze the increase in solar irradiance and its energy performance. For detailed analyses under specific location and weather conditions, the simulation techniques were used separately for prediction of solar irradiation [27,28] and energy production $[29,30]$. The proposed CPV consists of a photovoltaic panel and two highly reflective surfaces. The geometry and angle of the inclination of reflective surfaces were determined based on the Sun trace method using GeoGebra software [31]. The design of a low-concentration photovoltaic system was developed for a specific location and system dimensions. Subse- 
quently, the solar irradiance analysis was performed for the proposed CPV system using Radiance-lighting simulation software [28]. This approach allowed for precise determination of the solar radiation incident on PV panels within the characteristic time of the year and calculated the sum of irradiation during the specified period. Key parameters such as the accumulated annual solar energy and the uniformity of solar irradiance were analyzed compared to reference PV panels without reflective surfaces. Moreover, the energy performance and temperature characteristics of developed CPV were investigated numerically using ESP-r software [32]. It was found that the implementation of reflective surfaces would effectively increase the annual power electric production, but overheating could represent a thermal risk to the photovoltaic panels. However, in spite of overheating, the annual efficiency increases when reflective surfaces are added, and it is related to the effect of solar concentration on energy generation. In other words, the increase in electric power generation is greater than the increase in thermal losses, resulting in a positive energy balance.

\section{Methodology}

2.1. Geometric Design of Reflective Surfaces for PV Panels

\subsubsection{Design Considerations}

A flexible PV panel is considered to perform the geometrical design of the system. Its dimensions are described in Table 2.

Table 2. Geometric specifications of flexible PV panels.

\begin{tabular}{cccc}
\hline Dimension & Nomenclature & Value & Unit \\
\hline Largest side & $\mathrm{L}$ & 873 & $\mathrm{~mm}$ \\
Shortest side & 1 & 411 & $\mathrm{~mm}$ \\
Largest cell module side & $\mathrm{L}_{\mathrm{c}}$ & 760 & $\mathrm{~mm}$ \\
Shortest cell module side & $\mathrm{l}_{\mathrm{c}}$ & 360 & $\mathrm{~mm}$ \\
Thickness at module & $\mathrm{t}$ & 2.2 & $\mathrm{~mm}$ \\
Thickness at J-box & $\mathrm{e}$ & 21 & $\mathrm{~mm}$ \\
Weight & $\mathrm{w}$ & 0.8 & $\mathrm{~kg}$ \\
\hline
\end{tabular}

Both considered positions for the PV panel are shown in Figure 1. Regarding the orientation, it is facing the south axis, then the optimal slope corresponds to the solar midday sun position (Figure 2), so that the solar radiation reaches perpendicularly to the $\mathrm{PV}$ panel. In order to increase the solar radiation that impinges into the PV panel, two reflective surfaces (RS) are added to it. Then $a_{v}, a_{h}$, and the angles between RS and PV $(\theta, \varphi)$ panel are determined by sun-trace performed in GeoGebra software.

(a)

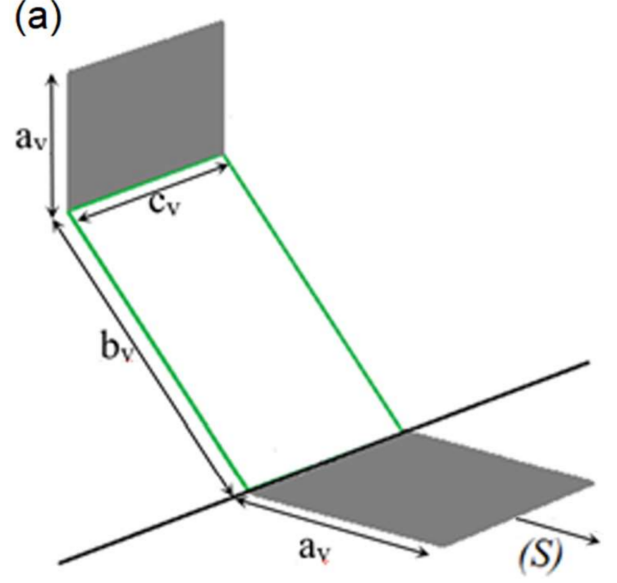

(b)

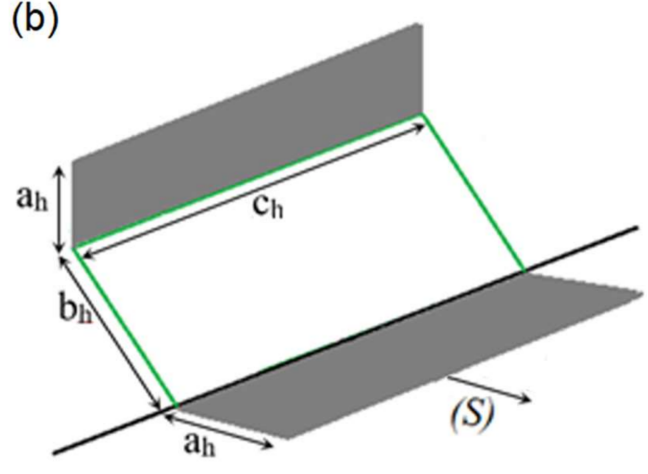

Figure 1. Positions for the PV panel facing to the South axis, and the fixed reflective surfaces. (a) vertical position. (b) horizontal position. 


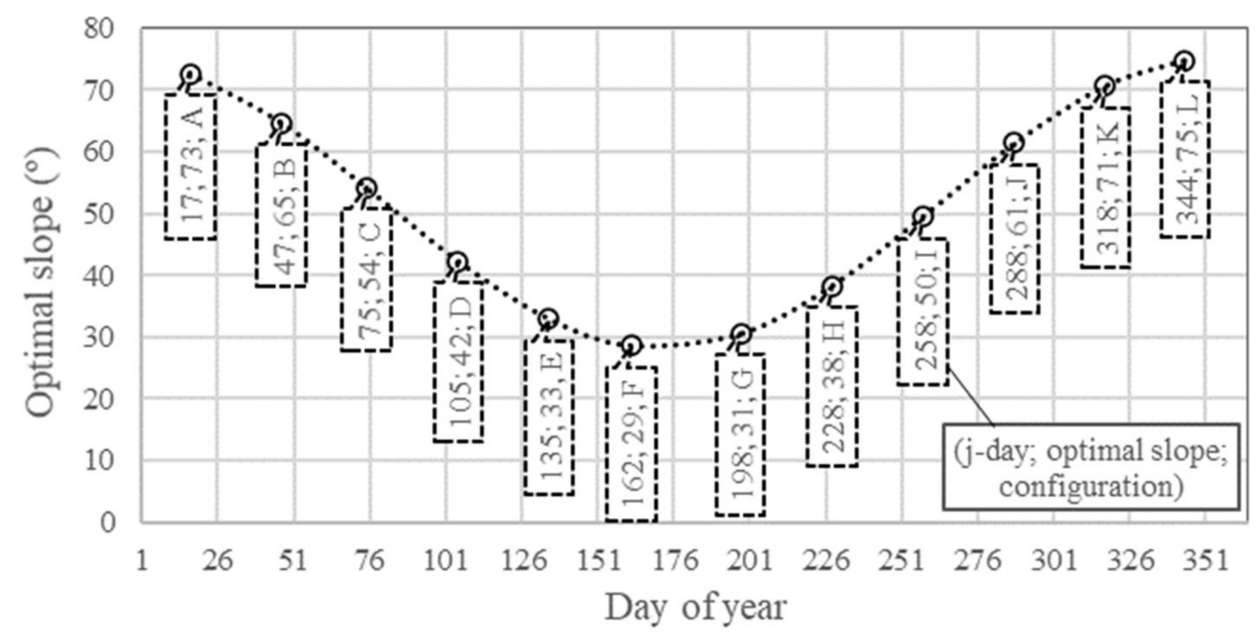

Figure 2. Optimal slope of PV panels for each monthly characteristic j-day. Location: Lodz, Poland (Latitude: $51.75^{\circ}$; Longitude: $19.45^{\circ}$, a.a.s.1.: $278 \mathrm{~m}$ ). Optimal angles were determined by using Geosol open access software [33]. A-L corresponds to the different configuration of PV panels for every single month.

\subsubsection{Geometric Design}

A single sun-tracing was performed for the RS design. The configuration for all RS is fixed in relation to the PV panel, and the slope of it varies for each monthly characteristic Julian day. The sizing and configuration of the RS were performed using GeoGebra software (69 Altenbergerstraße street, Linz, Austria) as can be seen in Figure 3, at 10 June. For this study, all the reflected sunrays impinge the whole PV panel extension. Then, it is receiving both reflected and global radiation. The dimensions of the reflective surfaces and their relative angles from the PV panel are shown in Table 3. These RS dimensions and relative configuration remain invariable during the whole year.

(a)

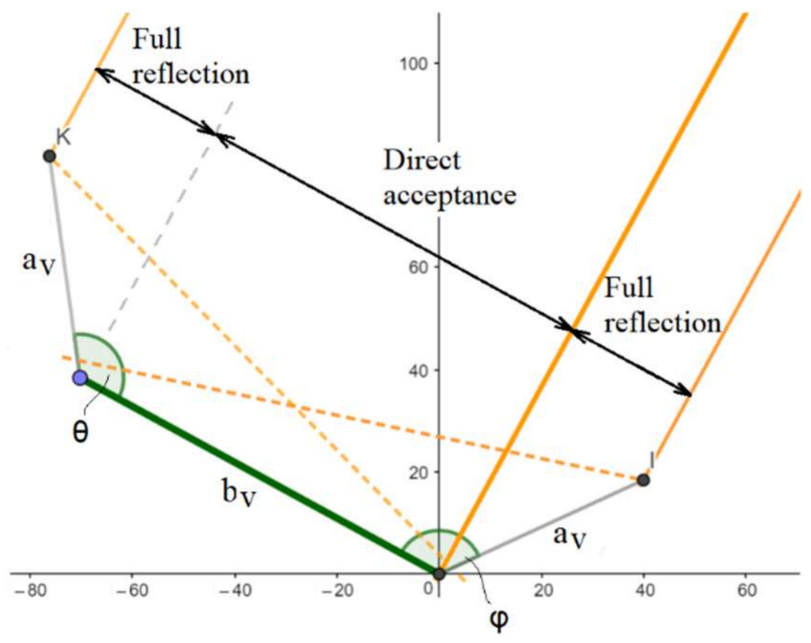

(b)

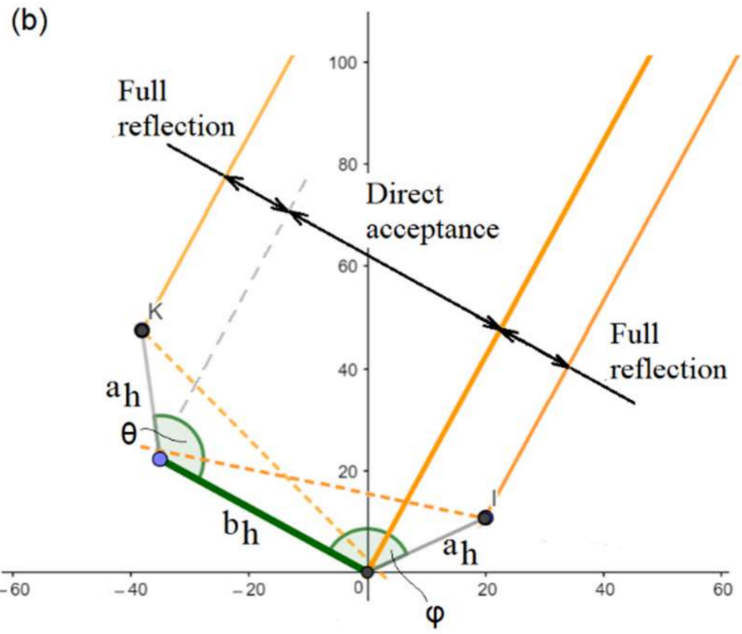

Figure 3. Geometric design performed by GeoGebra software for 10 June midday. Both parallel sunrays mark the limit of solar incidence at extreme borders of reflective surfaces (points $\mathrm{K}$ and I). Therefore, the direct acceptance and full reflection zones are identified. (a) vertical position. (b) horizontal position. 
Table 3. GeoGebra results. Geometry of reflective surfaces.

\begin{tabular}{cccc}
\hline Dimension & Symbol & Vertical Position & Horizontal Position \\
\hline Top RS angle (from panel) & $\theta$ & $126.6^{\circ}$ & $126.6^{\circ}$ \\
Top RS length & $c_{\mathrm{v}} ; c_{h}$ & $400 \mathrm{~mm}$ & $800 \mathrm{~mm}$ \\
Top RS width & $\mathrm{a}_{\mathrm{v}} ; \mathrm{a}_{\mathrm{h}}$ & $440 \mathrm{~mm}$ & $220 \mathrm{~mm}$ \\
Bottom RS angle (from panel) & $\varphi$ & $126.6^{\circ}$ & $126.6^{\circ}$ \\
Bottom RS length & $c_{\mathrm{v}} ; c_{\mathrm{h}}$ & $400 \mathrm{~mm}$ & $800 \mathrm{~mm}$ \\
Bottom RS width & $\mathrm{a}_{\mathrm{v}} ; \mathrm{a}_{\mathrm{h}}$ & $440 \mathrm{~mm}$ & $220 \mathrm{~mm}$ \\
\hline
\end{tabular}

Since the optimal configuration of the PV panel corresponds with the frontal solar incidence, the maximum solar energy collection is expected to be at solar midday for fixed systems. For this midday solar position, Figure 3 shows the different acceptance zones for all sunrays that reach the system parallel to the main sunray, which is taken as reference. It is firstly identified the direct acceptance range, where the solar radiation impinges to the PV panel without any previous reflection. Then, two full reflection zones are identified. They are compounded by the two RS that reflect the solar radiation into the PV panel. These three regions form the solar aperture segment, which measure $1.323 \mathrm{~m}$ and $0.663 \mathrm{~m}$ for both vertical and horizontal positions, respectively. Then, the total aperture areas count $\mathrm{S}_{\mathrm{v}}=1.32 \mathrm{~m} \times 0.44 \mathrm{~m}=0.58 \mathrm{~m}^{2}$, and $\mathrm{S}_{\mathrm{h}}=0.663 \mathrm{~m} \times 0.8 \mathrm{~m}=0.53 \mathrm{~m}^{2}$. On the other hand, the effective area of solar collection of the PV panel is considered as the area for the solar cell arrayment, which is $\mathrm{S}_{\mathrm{c}}=\mathrm{L}_{\mathrm{c}} \times \mathrm{l}_{\mathrm{c}}=0.27 \mathrm{~m}^{2}$, where $\mathrm{L}_{\mathrm{c}}$ and $\mathrm{l}_{\mathrm{c}}$ are the length and width of panel, respectively. The geometric concentration ratios are $\mathrm{C}_{\mathrm{v}}=\mathrm{S}_{\mathrm{v}} / \mathrm{S}_{\mathrm{c}}=2.1$, and $C_{h}=S_{h} / S_{c}=1.96$. However, the concentration ratio is only valid for the solar midday when the PV panel has been exposed to both direct and reflected sunrays. For morning and afternoon periods, the concentration ratio is lower.

\subsection{Numerical Analysis}

\subsubsection{Solar Irradiance Analysis}

The numerical investigation of the energy performance of PV panels equipped with reflective surfaces was performed in two stages. The first part is dedicated to the analysis of solar irradiance incidents on the surface of PV panels. In the second, the energy performance and temperature of the PV panels were determined using the ESP-r software.

Solar radiation incident on the PV panels with consideration of reflected rays from highly reflective surfaces was performed using the Radiance simulation engine combined with the Blender software by VI-Suite addon [27]. Radiance Lighting Simulation and Visualization software is a comprehensive and validated tool for lighting simulation. Moreover, Radiance is highly recognized among designers and researchers in the field of daylight analysis [34]. The Radiance simulation engine is based on a hybrid approach of ray tracing and Monte Carlo [28]. The geometry of the analyzed concentrating PV system was modeled using the Blender tool, which provides modeling, rendering, and visualization capabilities. The simulation was performed using the VI-Suite addon allowing the transformation of geometry developed in Blender to Radiance geometry files, simulation using the Radiance engine, and visualization of results of solar radiation calculations in Blender.

The geometry of PV panels and reflective surfaces was modeled regarding the dimensions determined in Section 2. The material properties of the individual surfaces are presented in Table 4 . The PV panels' surface was defined as plastic material and the reflective surfaces as mirrors according to the Radiance material definition. The optical parameters for the PV panels were defined based on [28,35]. The optical characteristics of the reflective surfaces were adopted according to the study of highly reflective materials presented in [36]. 
Table 4. Optical properties of materials used in solar radiation analysis.

\begin{tabular}{ccccccc}
\hline \multirow{2}{*}{ Surface } & \multirow{2}{*}{ Material Type } & \multicolumn{5}{c}{ Optical Properties } \\
\cline { 3 - 7 } & & R & G & B & Roughness & Specularity \\
\hline PV panel & plastic & 0.1 & 0.1 & 0.1 & 0.00 & 0.07 \\
Reflective surfaces & mirror & 0.853 & 0.839 & 0.820 & - & - \\
\hline
\end{tabular}

Solar radiation calculations were performed using weather data defined by the typical meteorological year (TMY) for the location of Lodz, Poland (Latitude: $51.75^{\circ}$; Longitude: $19.45^{\circ}$ ). The TMY used in the simulations according to the VI-Suite instructions was downloaded from the Energy Plus website (https:/ / energyplus.net/weather, accessed on 21 July 2021) [37]. Weather data consist of hourly values of solar radiation, temperature, wind direction and velocity, pressure, and humidity for a one-year period. Considering all these parameters is important, since in real-time test scenarios, certain weather conditions affect the performance of the solar panel's performance, resulting in significant voltage loss, an example here being the temperature [38].

The study was performed for twelve configurations of the PV panels defined to south direction with inclination angle regarding the optimal slopes of PV panels for each month according to the calculations presented in Section 2. In addition, solar radiation was determined for concentrating PV systems and for reference PV panels without reflective surfaces. Furthermore, both positions (vertical and horizontal) of the PV panels were considered.

\subsubsection{Distribution of Solar Irradiance}

The results of the first part of the numerical analysis were presented in the form of rendering maps of cumulative annual solar irradiance for vertical (Tables 5 and 6) and horizontal positions (Table 7) of PV panels. In addition, the annual values of the following parameters are presented in the tables. Values were calculated for the entire year, such as the average total annual solar irradiance $\left(\mathrm{I}_{\mathrm{av}}\right)$, the difference between average total annual solar irradiance of PV panels equipped with reflective surfaces and reference PV panels $\left(\Delta \mathrm{I}_{\mathrm{av}}\right)$, and the uniformity solar irradiance at concentrated PV system $(\mathrm{u})$. The last one was calculated according to the following formula:

$$
\mathrm{u}=\frac{\mathrm{I}_{\min }}{\mathrm{I}_{\max }}
$$

where $I_{\max }$ and $I_{\min }$ are the minimum and maximum solar energy densities on solar panel, respectively.

For calculation non-uniformity $(\mathrm{nu})$ of solar flux density the formula used by Wang et al. [39]:

$$
\mathrm{nu}=\frac{\mathrm{I}_{\max }-\mathrm{I}_{\min }}{\mathrm{I}_{\max }+\mathrm{I}_{\min }}
$$

The distribution of solar irradiance for reference PV panels is uniform and the same for the vertical and horizontal positions of $\mathrm{PV}$ panels. The highest value of solar irradiance is observed for cases E, F, and G with the $\mathrm{I}_{\mathrm{av}}$ higher than $1080\left[\mathrm{kWh} /\left(\mathrm{m}^{2}\right.\right.$ year $\left.)\right]$.

However, the solar irradiance maps for the concentrating PV systems were inhomogeneous with the highest value at the bottom of the PV panel. Moreover, different distributions of solar radiation intensity were observed at vertically and horizontally positioned PV panels. However, the highest annual solar irradiance for CPV systems was observed for cases $\mathrm{D}, \mathrm{E}, \mathrm{G}$, and $\mathrm{H}$ with a value greater than $1150\left[\mathrm{kWh} /\left(\mathrm{m}^{2}\right.\right.$ year $\left.)\right]$ for vertical and $1190\left[\mathrm{kWh} /\left(\mathrm{m}^{2}\right.\right.$ year $\left.)\right]$ for horizontal positions of PV panels. The highest increase in annual solar irradiance was observed for case $\mathrm{D}$, both for the vertical position (more than $7 \%$ ) and horizontal position (more than 10\%) of the PV panel. 
Table 5. Solar irradiance characteristic for A-F cases of PV panels positioned vertically.

\begin{tabular}{|c|c|c|c|c|c|c|c|c|}
\hline & & \multicolumn{7}{|c|}{ Total Annual Solar Irradiance I [kWh/(m ${ }^{2}$ Year $\left.)\right]$} \\
\hline \multirow{15}{*}{\multicolumn{2}{|c|}{ 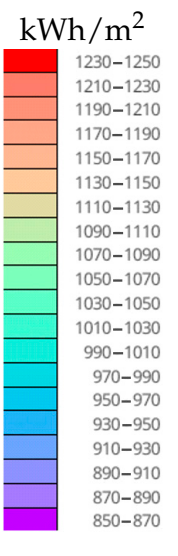 }} & \multirow{6}{*}{$\begin{array}{c}\text { Reference PV } \\
\text { panel }\end{array}$} & & & & & & \\
\hline & & & & & & & & \\
\hline & & & & & & & & \\
\hline & & & & & & & & \\
\hline & & & & & & & & \\
\hline & & & & & & & & \\
\hline & & $\mathrm{I}_{\mathrm{av}}$ & 865.9 & 936.8 & 1013.3 & 1065.1 & 1080.8 & 1081.3 \\
\hline & & \multirow{7}{*}{$\begin{array}{c}\text { Concentrated } \\
\text { PV system }\end{array}$} & & & & & & 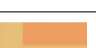 \\
\hline & & & & & & & & \\
\hline & & & & & & & & \\
\hline & & & & & & & & \\
\hline & & & n & & & & & \\
\hline & & & & & & & & \\
\hline & & & & & & & & E \\
\hline & & $\mathrm{I}_{\mathrm{av}}$ & 911.7 & 1004.0 & 1095.6 & 1152.9 & 1158.7 & 1149.4 \\
\hline \multicolumn{3}{|c|}{$\Delta \mathrm{I}_{\mathrm{av}}\left[\mathrm{kWh} /\left(\mathrm{m}^{2}\right.\right.$ year $\left.)\right]$} & 45.7 & 67.2 & 82.3 & 87.8 & 78.0 & 68.2 \\
\hline \multicolumn{3}{|c|}{$\mathrm{u}[-]$} & 0.93 & 0.92 & 0.89 & 0.89 & 0.92 & 0.93 \\
\hline \multicolumn{3}{|c|}{ nu [-] } & 0.04 & 0.04 & 0.06 & 0.06 & 0.04 & 0.03 \\
\hline \multirow{2}{*}{\multicolumn{3}{|c|}{ Configuration (Month) }} & $\mathrm{A}$ & B & $\mathrm{C}$ & $\mathrm{D}$ & $\mathrm{E}$ & $\mathrm{F}$ \\
\hline & & & (Jan) & (Feb) & (Mar) & (Apr) & (May) & (Jun) \\
\hline
\end{tabular}

Table 6. Solar irradiance characteristic for G-L cases of PV panels positioned vertically.

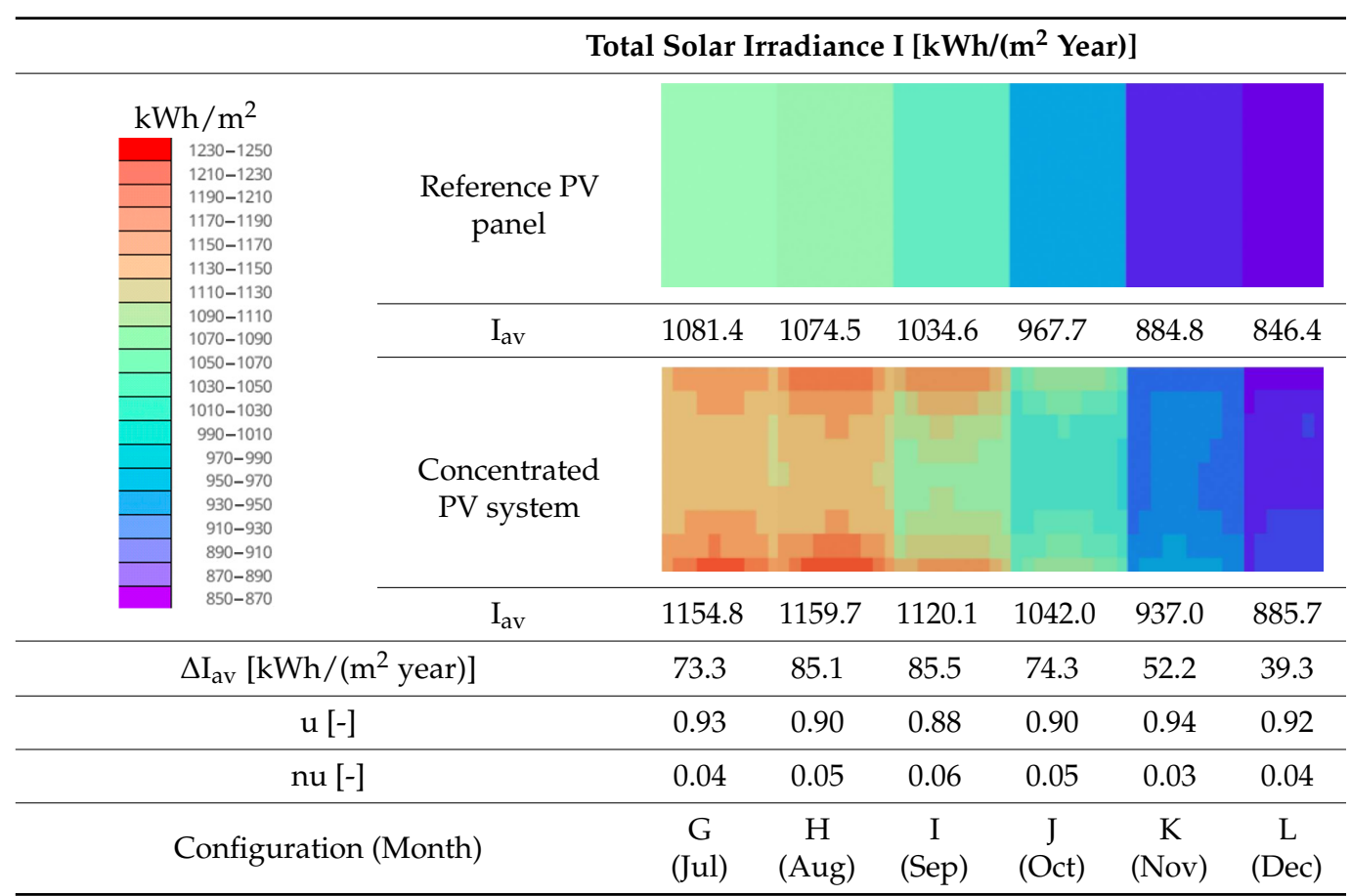


Table 7. Solar irradiance characteristic for cases of PV panels positioned horizontally.

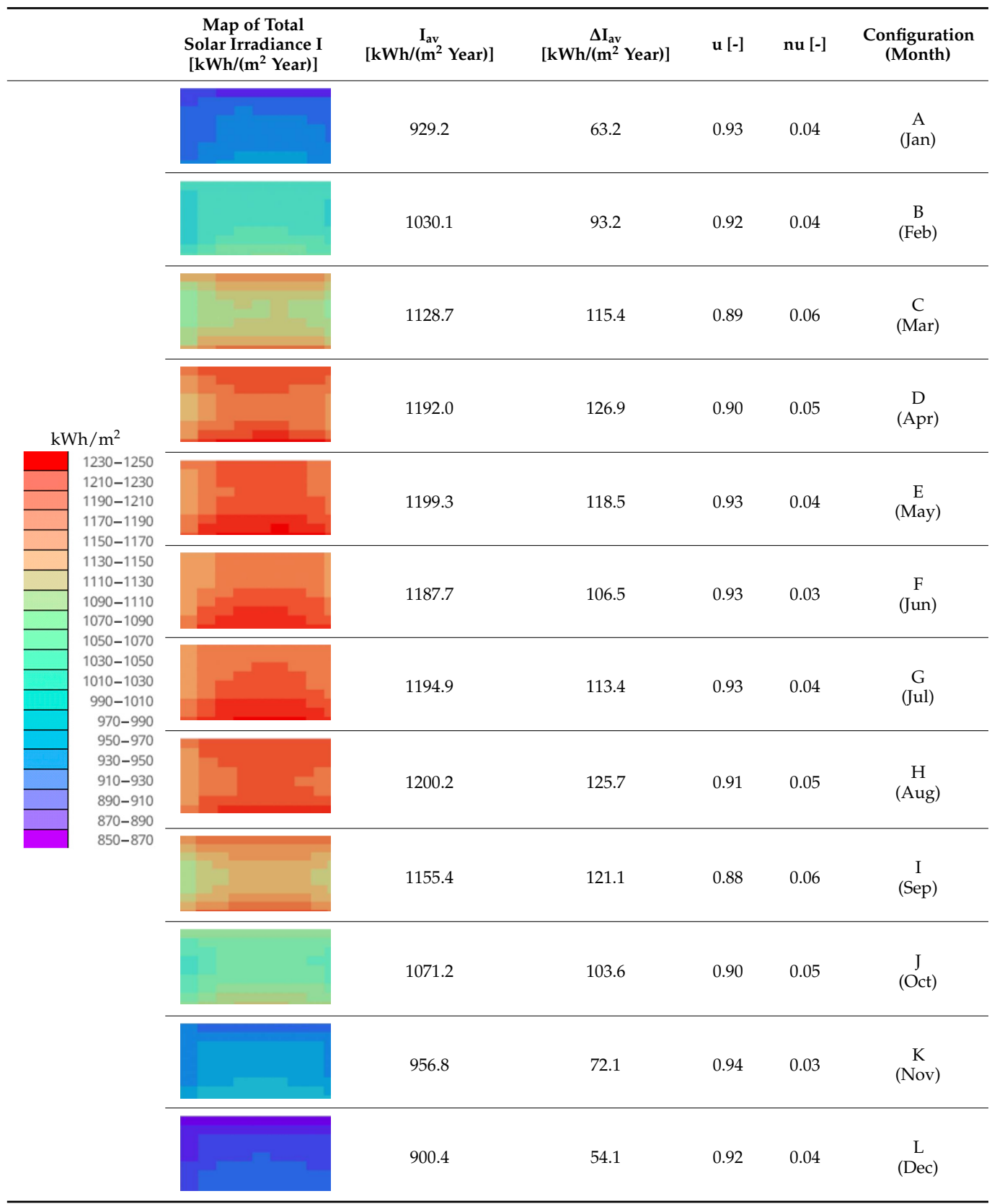

The cumulative monthly result of solar irradiance for each case is presented in Figures 4-6. The highest solar radiation intensity for reference and concentrating PV systems is in the months from May to July, which corresponds to the solar radiation availability characteristics for the analyzed location-Lodz. Furthermore, in these months, the highest results were observed for cases E, F, and G. In the winter months (January, February, November, and December), for these cases (E, F, and G), the impact of reflective surfaces is not noticeable. 


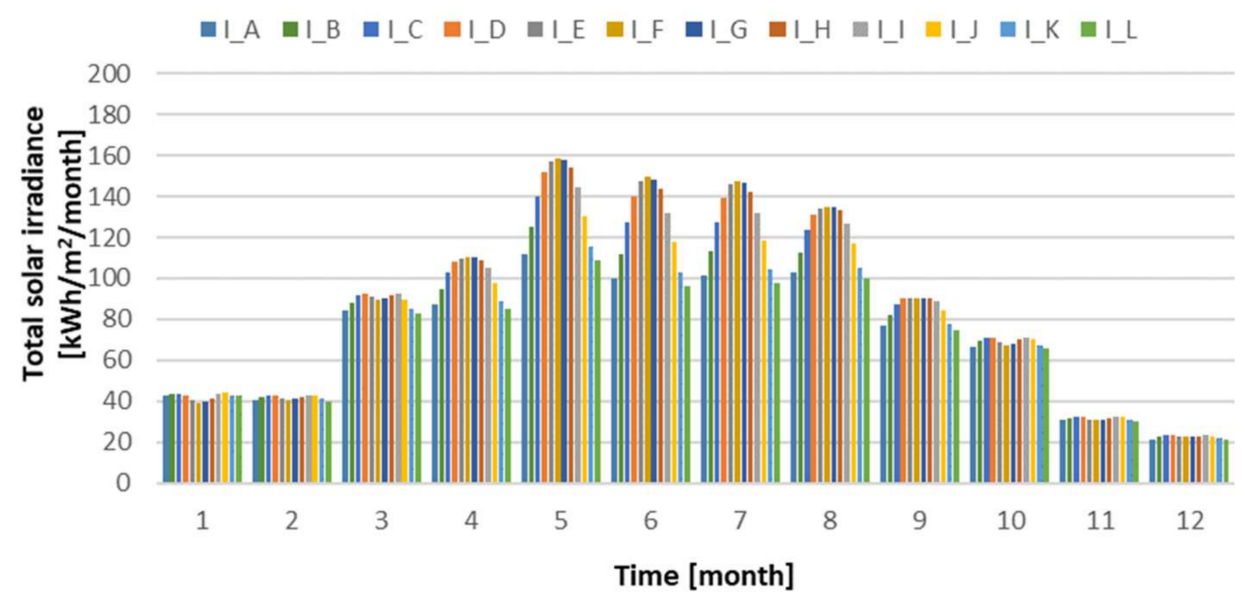

Figure 4. Total monthly solar irradiance incident on reference PV panels.

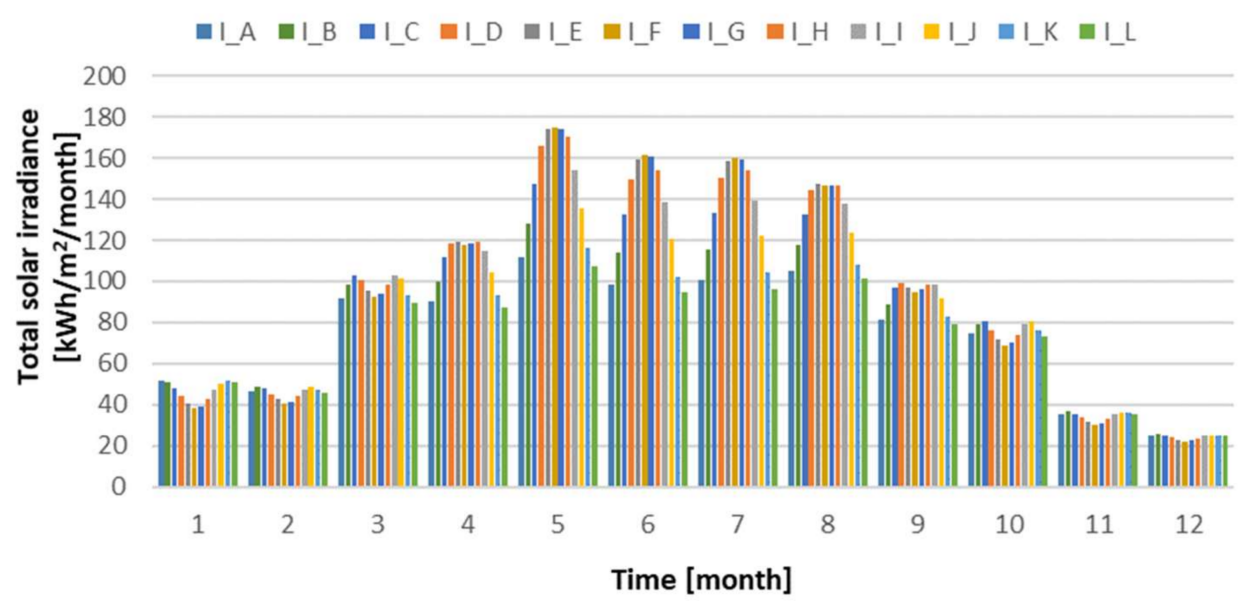

Figure 5. Total monthly solar irradiance incident on vertically positioned PV panels equipped with reflective surfaces.

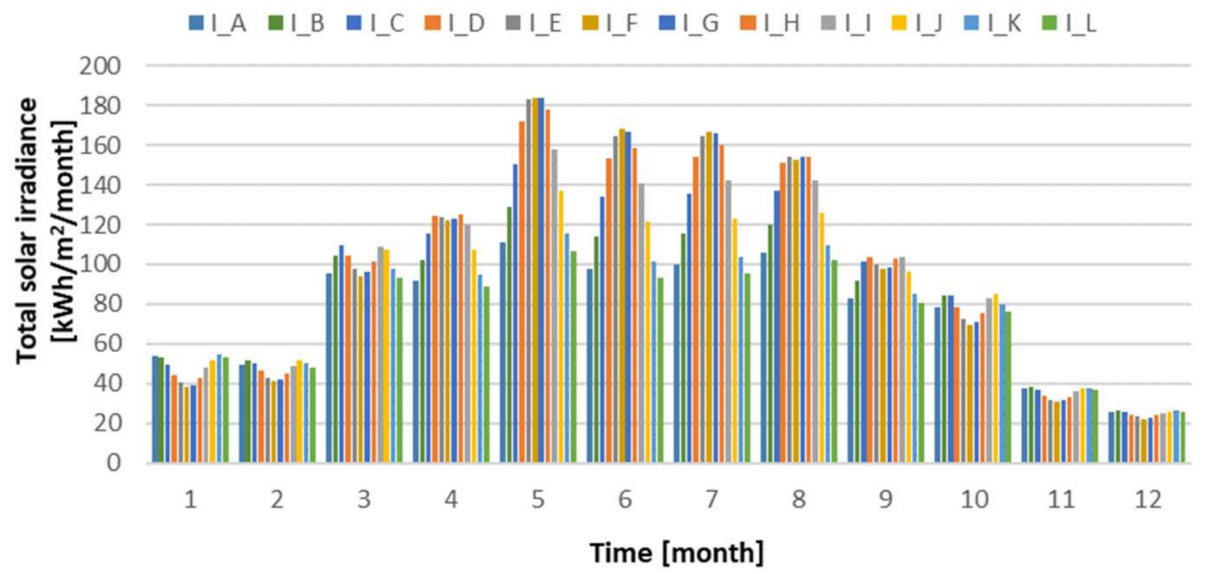

Figure 6. Total monthly solar irradiance incident on horizontally positioned PV panels equipped with reflective surfaces.

\subsubsection{Energy Performance Analysis for Single Panel}

The subsequent part of the numerical analysis was devoted to investigating the influence of reflective surfaces on the energy performance and temperature of PV panels. The study was carried out using ESP-r software, the multi-domain simulation tool for comprehensive modeling of buildings, including the energy flow, the indoor environment, or renewable energy sources [32]. In ESP-r the photovoltaic conversion can be modeled 
using one of three models: a simple model with constant PV cell efficiency, Kelly's model, and WATSUN-PV model. In the paper presented the WATSUN-PV model was used due to the most advanced consideration of the impact of cell temperature on the voltage and current of PV panels [40] as presented in Equations (3) and (4).

$$
\begin{gathered}
\mathrm{I}_{\mathrm{sc}}=\mathrm{I}_{\mathrm{sc}, \text { ref }} \frac{\mathrm{E}_{\mathrm{T}, \text { eff }}}{\mathrm{E}_{\mathrm{T}, \mathrm{ref}}}\left[1+\alpha\left(\mathrm{T}_{\text {cell }}-\mathrm{T}_{\text {cell,ref }}\right)\right] \\
\mathrm{V}_{\mathrm{oc}}=\mathrm{V}_{\mathrm{oc}, \text { ref }}\left[1-\gamma\left(\mathrm{T}_{\text {cell }}-\mathrm{T}_{\text {cell, ref }}\right)\right] \cdot \max \left\{01+\beta \cdot \ln \left(\frac{\mathrm{E}_{\mathrm{T}, \text { eff }}}{\mathrm{E}_{\mathrm{T}, \text { ref }}}\right)\right\}
\end{gathered}
$$

where:

$\mathrm{I}_{\mathrm{sc}}$ - the short circuit current [A];

$\mathrm{V}_{\mathrm{oc}}$ - the open circuit voltage [V];

$\mathrm{I}_{\mathrm{sc}, \text { ref }}$-short circuit current in reference conditions [A];

$\mathrm{V}_{\mathrm{oc}, \mathrm{ref}}$ - open circuit voltage in reference conditions [V];

$\mathrm{E}_{\mathrm{T}, \text { eff }}$ - effective irradiance incident on the surface of PV cell $\left[\mathrm{W} / \mathrm{m}^{2}\right]$;

$\mathrm{E}_{\mathrm{T}, \mathrm{ref}}$-irradiance incident on the PV surface in reference conditions, $\mathrm{E}_{\mathrm{T}, \mathrm{ref}}=1000 \mathrm{~W} / \mathrm{m}^{2}$;

$\mathrm{T}_{\text {cell }}-\mathrm{PV}$ cell temperature $\left[{ }^{\circ} \mathrm{C}\right]$

$\mathrm{T}_{\text {cell,ref }}-\mathrm{PV}$ cell temperature in reference conditions, $\mathrm{T}_{\text {cell,ref }}=25^{\circ} \mathrm{C}$

$\alpha$-temperature coefficient of $\mathrm{I}_{\mathrm{sc}}\left[1 /{ }^{\circ} \mathrm{C}\right]$

$\gamma$-temperature coefficient of $\mathrm{V}_{\mathrm{oC}}\left[1 /{ }^{\circ} \mathrm{C}\right]$

$\beta$-irradiance coefficient of $\mathrm{V}_{\mathrm{oc}}$ assumed as $0.0681[-]$

The power of PV panel, $\mathrm{P}_{\mathrm{mpp}}$, is calculated in relation to calculated and reference the short circuit current and open circuit voltage, (Equation (5)):

$$
\mathrm{P}_{\mathrm{mpp}}=\mathrm{I}_{\mathrm{mpp}, \mathrm{ref}} \cdot \mathrm{V}_{\mathrm{mpp}, \text { ref }}\left(\frac{\mathrm{I}_{\mathrm{sc}} \cdot \mathrm{V}_{\mathrm{oc}}}{\mathrm{I}_{\mathrm{sc}, \mathrm{ref}} \cdot \mathrm{V}_{\mathrm{oc}, \text { ref }}}\right)
$$

where:

$\mathrm{I}_{\mathrm{mp}, \mathrm{ref}}$-maximum power point current in reference conditions [A]

$\mathrm{V}_{\mathrm{mp} \text {,ref }}$-maximum power point voltage in reference conditions [V]

The electrical parameters for calculations were assumed according to data of a flexible CIGS PV panel of Flisom company presented in Table 8.

Table 8. Electrical parameters of PV panels.

\begin{tabular}{cccc}
\hline Parameter & Symbol & Value & Unit \\
\hline Power at maximum power point & $\mathrm{P}_{\mathrm{mpp} \text {,ref }}$ & 30 & $\mathrm{~W}$ \\
Voltage at $\mathrm{P}_{\mathrm{mpp}}$ & $\mathrm{V}_{\mathrm{mpp} \text {,ref }}$ & 34 & $\mathrm{~V}$ \\
Current at $\mathrm{P}_{\mathrm{mpp}}$ & $\mathrm{I}_{\mathrm{mpp} \text {,ref }}$ & 0.88 & $\mathrm{~A}$ \\
Open circuit voltage & $\mathrm{V}_{\mathrm{oc} \text {,ref }}$ & 46 & $\mathrm{~V}$ \\
Short circuit current & $\mathrm{I}_{\mathrm{sc} \text { ref }}$ & 0.97 & $\mathrm{~A}$ \\
Temperature coefficient of $\mathrm{V}_{\mathrm{oc}}$ & $\gamma$ & -0.3 & $\% /{ }^{\circ} \mathrm{C}$ \\
Temperature coefficient of $\mathrm{I}_{\mathrm{sc}}$ & $\alpha$ & 0.01 & $\% /{ }^{\circ} \mathrm{C}$ \\
\hline
\end{tabular}

ESP-r software has been developed extensively in the context of building performance simulation. However, the solar radiation is calculated on the data from a meteorological year without interreflections between surrounding surfaces. Therefore, the total solar radiation incident on the analyzed concentrating PV system was calculated using the Radiance engine. Subsequently, the obtained result file was implemented into the ESP-r model as a boundary condition in the form of a temporal file.

The remaining meteorological data, such as air temperature, wind direction and velocity, air pressure and humidity were assumed according to the same weather data as in the first part of the analysis. 


\subsubsection{Energy Performance Analysis for the Selected Configuration of Panels}

The second part of the analysis was performed for three selected PV panel configurations of $\mathrm{PV}$ panels due to the highest total annual solar irradiance (case $\mathrm{H}$ ), the highest increase in total annual solar irradiance of PV panels with reflective surfaces compared to the reference PV panels (case D), and the optimal slope of PV panels for the entire year (case G).

Furthermore, the application of the proposed concentrating PV system is only reasonable in the form of an installation consisting of several adjacent panels equipped with highly reflective surfaces. For the purpose of energy performance calculations, the authors assumed a single row of twelve vertically positioned PV panels equipped with reflective surfaces. The solar irradiance for the described installations are presented in Table 9. Reflective surfaces located at the top and bottom of PV panels affect the non-uniform distribution of solar irradiance with the highest intensity in the upper and lower parts of the panel. Therefore, the ESP-r calculations assumed the average value of solar irradiance incident on PV panels. Solar irradiance was determined for every hour throughout the whole year.

Table 9. Distribution of annual solar irradiance for rows consisting of twelve PV panels positioned vertically for $\mathrm{D}, \mathrm{H}$ and $\mathrm{G}$ cases.

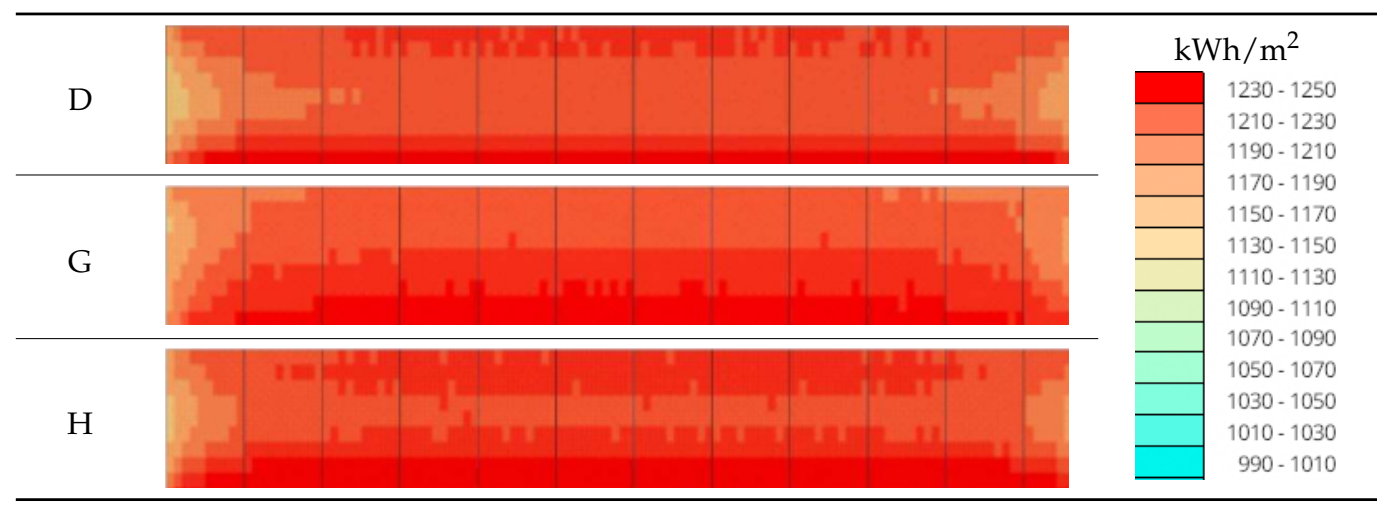

\section{Results}

In this section, the results of the energy performance and temperature of PV panels are presented. In Figure 7, the total monthly energy generated by the CPV systems and reference PV panels is shown. In the winter months (January, February, November, and December), the impact of reflective surfaces is very small and the increase in energy does not exceed 10\%. Whereas in the spring and summer months (May, June, July, and August) the energy generated from CPV systems is higher than from reference PV panels about $15-20 \%$. The annual increase is at the level of $16 \%$ for cases D and H, $14 \%$ for G case.

The next figures are devoted to a comparison of the temperature of CPV systems and reference PV panels. In Figure 8 the operating temperatures of the PV surface (average, maximum and minimum) are shown. The highest differences are noticeable for the maximum temperature, with an increase of about $30 \%$ for cases D and $\mathrm{H}$ and $15 \%$ for case G. The average and minimum temperatures for the analyzed cases were comparable. The last Figure 9 presents the monthly degree hours of $\mathrm{CPV}$ overheating compared to the reference photovoltaic panels. The highest overheating degree hours were registered for May, and in the summer months (May - July) the panels in configuration $G$ were the most overheated, while for the other months, configuration D had the highest value of degree hours. 


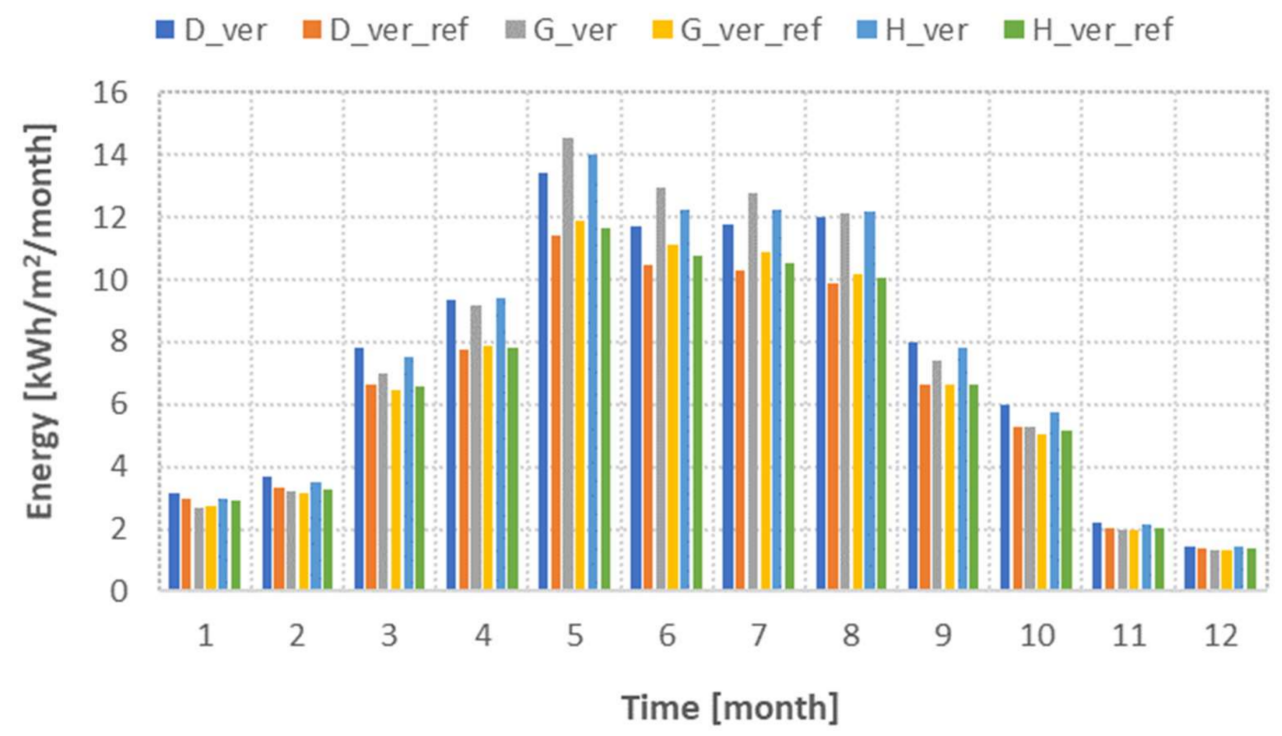

Figure 7. Total monthly energy generated by PV panels.

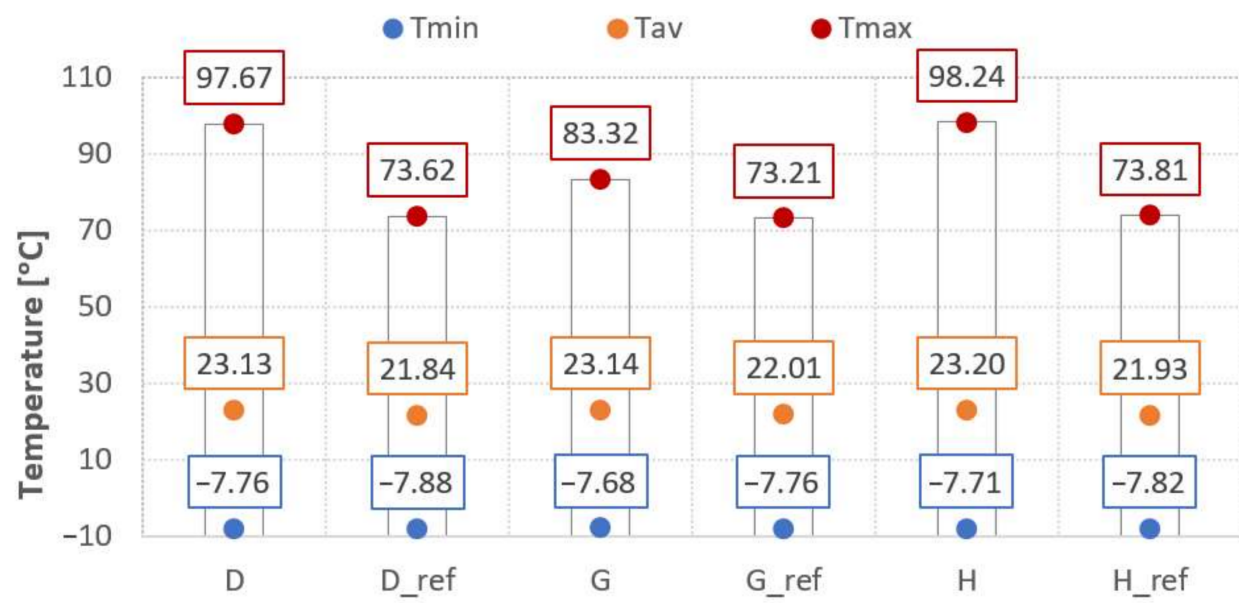

Figure 8. Temperature range of PV panels including minimum, maximum and average temperature during operation of PV panels.

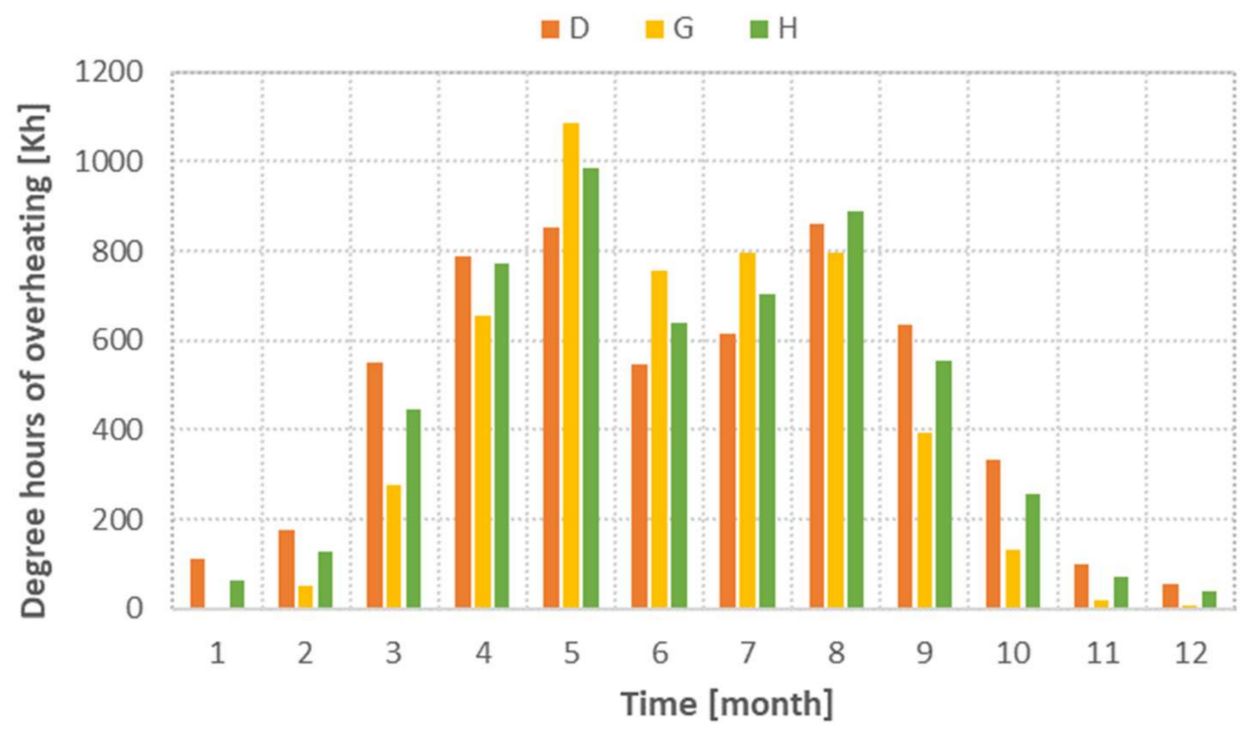

Figure 9. Degree hours of overheating of PV panels equipped with reflective surfaces. 
The overheating of photovoltaic panels and non-uniform illumination can have a disadvantageous effect on their efficiency, but on the other hand, the higher intensity of solar radiation can increase the overall production [41]. In comparison to the reference case the annual average efficiency slightly increased for all cases (Table 10). There are no visible differences in the efficiency of PV between cases D, G and H. As expected, the annual average efficiency of the whole concentrating system is higher around $0.6 \%$ in comparison with the reference case.

Table 10. Average annual efficiency.

\begin{tabular}{ccccccc}
\hline Case & D & D_ref & G & G_ref & H & H_ref \\
\hline $\begin{array}{c}\text { Annual average efficiency of } \\
\text { photovoltaic panels [\%] }\end{array}$ & 6.73 & 6.66 & 6.73 & 6.67 & 6.73 & 6.67 \\
\hline $\begin{array}{c}\text { Annual average efficiency of low } \\
\text { concentrating system [\%] }\end{array}$ & 7.34 & - & 7.20 & - & 7.31 & - \\
\hline
\end{tabular}

\section{Discussion}

The geometrically optimized solar reflected system for PV panels installed in a row provided an improvement in solar energy density, but a high uniformity in its distribution and temperature of the panel was not achieved. The annual average increase in solar intensity varies from 4.4 to $10.6 \%$ depending on the position and configuration of CPV. The biggest disadvantages of the proposed solution that influence productivity are the uniformity of solar radiation and the temperature increase of the panel.

The uniformity/non-uniformity was analyzed by two coefficients determined bases of the simulation results. Compared to the results obtained by Wang et al. [39] for the multi-segment plate concentrator (uniformity 0.8), our values were substantially higher at the level of 0.94-0.97, determined on the yearly data for different configurations. As it was expected, there is very low impact of reflected surfaces in winter months when diffuse radiation dominates.

The effect of increasing solar radiation that is converted into heat in some areas of PV panels caused the temperature difference at its surface and the problem of overheating. It was noticed that in the case of configurations $\mathrm{D}$ and $\mathrm{H}$, which was the optimal one for April and August, the temperature exceeds $85^{\circ} \mathrm{C}$. This can lead after hours of exposure to reduction in the average normalized maximum power. Moreover, cell damage can be observed as an effect of high temperature, which is known as a hot spot effect that can possibly be solved by using bypass diodes.

Even though the temperature of the panel is additionally irradiated by reflected solar flux increasing and irradiation is non-uniform, the overall monthly energy production rises during the whole year. The relative difference is from $10 \%$ in winter to $20 \%$ in summer, depending on the configurations. It can be also noticed that the effect on energy production is positive for all configurations.

\section{Conclusions}

Two opposite flat reflected metal surfaces were proposed to improve the energy performance of PV panels. Technically, the proposed solution is easily applicable, lowcost, and characterized by a constant geometry. The size and configuration determined at the beginning allows one to use such a system in a free standing installation. The main drawback of non-movable and flat reflectors is the asymmetrical spotlight on the PV surface. Even if the irradiation is irregular for all the analyzed cases, it leads to an increase of solar irradiation incident on the cells. On the other hand, some amount of solar flux is transferred into heat, causing local overheating, which could represent a thermal risk for PV panels.

The authors proposed different system configurations considering location, sun position, and slope angle of PV panels. Twelve different configurations were considered and 
numerically analyzed throughout the whole year, assuming the south orientation of the installation. The energy produced by PV panels equipped with reflected surfaces was observed to be higher than the reference one for all configurations. Even if the PV panel was overheated, the energy gains (due to the higher intensity of solar radiation) are higher than the energy loss (due to the panel overheating). It should be noted that in specific periods, the PV can be overheated above the limit level to avoid damage. Although the energy production is higher in comparison with the reference case (without reflected surfaces), the overall efficiency is almost the same. Annual power production was determined to improve by about $10 \%$ when low-concentration systems are included, and solar radiation presents the highest values in the summer months.

For further analyses with other reflective materials (mirror, for example), other PV types more sensitive for the direct solar radiation could be considered. Moreover, development of experimental set-up and full-scale measurement could be a next step for future research. By experiments, it would be possible to validate the computational model and test the installation under different real weather conditions. Moreover, further investigation towards improving the uniformity of solar flux density distribution could be a scope of future work.

Author Contributions: Conceptualization, P.R.D. and D.H.; methodology, D.K. and P.R.D.; software, D.K. and P.R.D.; formal analysis, D.K. and P.R.D.; investigation, D.K., P.R.D. and D.H.; data curation, D.K.; writing—original draft preparation, D.K., P.R.D. and D.H.; writing-review and editing, D.K., P.R.D. and D.H.; visualization, D.K. and P.R.D.; supervision, D.H. All authors have read and agreed to the published version of the manuscript.

Funding: This research received no external funding.

Institutional Review Board Statement: Not applicable.

Informed Consent Statement: Not applicable.

Data Availability Statement: Data sharing not applicable.

Acknowledgments: This research was partially supported by the Polish National Agency for Academic Exchange through the ULAM program, under decision No. PPN/ULM/2020/1/00118/DEC/1.

Conflicts of Interest: The authors declare no conflict of interest. The funders had no role in the design of the study; in the collection, analyses, or interpretation of data; in the writing of the manuscript, or in the decision to publish the results.

\section{References}

1. Xie, W.T.; Dai, Y.J.; Wang, R.Z.; Sumathy, K. Concentrated solar energy applications using Fresnel lenses: A review. Renew. Sustain. Energy Rev. 2011, 15, 2588-2606. [CrossRef]

2. Ryu, K.; Rhee, J.G.; Park, K.M.; Kim, J. Concept and design of modular Fresnel lenses for concentration solar PV system. Sol. Energy 2006, 80, 1580-1587. [CrossRef]

3. Sierra, C.; Vázquez, A.J. High solar energy concentration with a Fresnel lens. J. Mater. Sci. 2005, 40, 1339-1343. [CrossRef]

4. Miller, D.C.; Kurtz, S.R. Durability of Fresnel lenses: A review specific to the concentrating photovoltaic application. Sol. Energy Mater. Sol. Cells 2011, 95, 2037-2068. [CrossRef]

5. Hornung, T.; Steiner, M.; Nitz, P. Estimation of the influence of Fresnel lens temperature on energy generation of a concentrator photovoltaic system. Sol. Energy Mater. Sol. Cells 2012, 99, 333-338. [CrossRef]

6. Pérez-Higueras, P.; Muñoz, E.; Almonacid, G.; Vidal, P.G. High Concentrator PhotoVoltaics efficiencies: Present status and forecast. Renew. Sustain. Energy Rev. 2011, 15, 1810-1815. [CrossRef]

7. Royne, A.; Dey, C.J.; Mills, D.R. Cooling of photovoltaic cells under concentrated illumination: A critical review. Sol. Energy Mater. Sol. Cells 2005, 86, 451-483. [CrossRef]

8. Bigorajski, J.; Chwieduk, D. Analysis of a micro photovoltaic/thermal-PV/T system operation in moderate climate. Renew. Energy 2019, 137, 127-136. [CrossRef]

9. Shastry, D.M.C.; Arunachala, U.C. Thermal management of photovoltaic module with metal matrix embedded PCM. J. Energy Storage 2020, 28, 101312. [CrossRef]

10. Zhang, Y.; Shen, C.; Zhang, C.; Pu, J.; Yang, Q.; Sun, C. A novel porous channel to optimize the cooling performance of PV modules. Energy Built Environ. 2021. [CrossRef] 
11. Knera, D.; Heim, D. Application of a BIPV to cover net energy use of the adjacent office room. Manag. Environ. Qual. Int. J. 2016, 27, 649-662. [CrossRef]

12. Park, N.C.; Oh, W.W.; Kim, D.H. Effect of Temperature and Humidity on the Degradation Rate of Multicrystalline Silicon Photovoltaic Module. Int. J. Photoenergy 2013, 2013, 925280. [CrossRef]

13. Machniewicz, A.; Knera, D.; Heim, D. Effect of transition temperature on efficiency of PV/PCM panels. Energy Procedia 2015, 78, 1684-1689. [CrossRef]

14. Heim, D.; Wieprzkowicz, A.; Knera, D.; Ilomets, S.; Kalamees, T.; Špitalský, Z. Towards improving the durability and overall performance of pv-etics by application of a pcm layer. Appl. Sci. 2021, 11, 4667. [CrossRef]

15. Sornek, K.; Filipowicz, M.; Jasek, J. The Use of Fresnel Lenses to Improve the Efficiency of Photovoltaic Modules for Buildingintegrated Concentrating Photovoltaic Systems. J. Sustain. Dev. Energy Water Environ. Syst. 2018, 6, 415-426. [CrossRef]

16. Yamaguchi, M.; Takamoto, T.; Araki, K. Super high-efficiency multi-junction and concentrator solar cells. Sol. Energy Mater. Sol. Cells 2006, 90, 3068-3077. [CrossRef]

17. Stacey, R.W.; McCormick, P.G. Effect of concentration on the performance of flat plate photovoltaic modules. Sol. Energy 1984, 33, 565-569. [CrossRef]

18. Abella, M.A.; Chenlo, F.; Sánchez, J.; Rodríguez, C.; Fernández, J.A. Development and test of a polyhedral low-concentration mirror (3X) PV generator. In Proceedings of the 2009 34th IEEE Photovoltaic Specialists Conference (PVSC), Philadelphia, PA, USA, 7-12 June 2009; pp. 2208-2213.

19. Julajaturasirarath, S.; Jonburom, W.; Pornsuwancharoen, N. The experiment of double solar energy by reflection light method. Procedia Eng. 2012, 32, 522-530. [CrossRef]

20. Zainulabdeen, F.S.; Al-Hamdani, A.H.; Karam, G.S.; Ali, J.H. Improving the performance efficiency of solar panel by using flat mirror concentrator. AIP Conf. Proc. 2019, 2190, 20054.

21. Kuhn, T.E.; Erban, C.; Heinrich, M.; Eisenlohr, J.; Ensslen, F.; Neuhaus, D.H. Review of technological design options for building integrated photovoltaics (BIPV). Energy Build. 2021, 231, 110381. [CrossRef]

22. Scognamiglio, A. A trans-disciplinary vocabulary for assessing the visual performance of bipv. Sustainability 2021, $13,5500$. [CrossRef]

23. Jelle, B.P. Building integrated photovoltaics: A concise description of the current state of the art and possible research pathways. Energies 2016, 9, 21. [CrossRef]

24. Monteleone, A.; Rodonò, G.; Gagliano, A.; Sapienza, V. SLICE: An Innovative Photovoltaic Solution for Adaptive Envelope Prototyping and Testing in a Relevant Environment. Sustainability 2021, 13, 8701. [CrossRef]

25. Kim, A.A.; Reed, D.A.; Choe, Y.; Wang, S.; Recart, C. New building cladding system using independent Tilted BIPV panels with battery storage capability. Sustainability 2019, 11, 5546. [CrossRef]

26. Khan, M.A.; Zeb, K.; Uddin, W.; Sathishkumar, P.; Ali, M.U.; Hussain, S.; Ishfaq, M.; Himanshu; Subramanian, A.; Kim, H.J. Design of a building-integrated photovoltaic system with a novel Bi-reflector PV system (BRPVs) and optimal control mechanism: An experimental study. Electronics 2018, 7, 119. [CrossRef]

27. Southall, R.; Biljecki, F. The VI-Suite: A set of environmental analysis tools with geospatial data applications. Open Geospat. Data Softw. Stand. 2017, 2, 23. [CrossRef]

28. Ward, G.; Shakespeare, R. Rendering with Radiance: The Art and Science of Lighting Visualization; Morgan Kaufmann Publishers: San Francisco, CA, USA, 1998; p. 664.

29. Clarke, J.A.; Kelly, N.J.; Tang, D. A Review of ESP-r's Flexible Solution Approach and its Application to Prospective Technical Domain Developments. Adv. Build. Energy Res. 2007, 1, 227-247. [CrossRef]

30. Clarke, J.A.; Kelly, N.J. Integrating power flow modelling with building simulation. Energy Build. 2001, 33, 333-340. [CrossRef]

31. GeoGebra. 2021. Available online: https://www.geogebra.org/ (accessed on 4 April 2021).

32. Clarke, J. Energy Simulation in Building Design; Butterworth-Heinemann: Oxford, UK, 2001; p. 373.

33. Hernández, A.L. GEOSOL: Una herramienta computacional para el cálculo de coordenadas solares y la estimación de irradiación solar horaria. Av. Energías Renov. Medio Ambient. 2003, 7, 19-24.

34. Knera, D.; Heim, D. Determination of daylight conditions in office room using digital images as a light source. IOP Conf. Ser. Mater. Sci. Eng. 2018, 415, 012040. [CrossRef]

35. Taveres-Cachat, E.; Bøe, K.; Lobaccaro, G.; Goia, F.; Grynning, S. Balancing competing parameters in search of optimal configurations for a fix louvre blade system with integrated PV. Energy Procedia 2017, 122, 607-612. [CrossRef]

36. Echazú, R.; Cadena, C.; Saravia, L. Estudio de materiales reflectivos para concentradores solares. Av. Energías Renov. Medio Ambient. 2000, 4, 11-16.

37. EnergyPlus—Weather Data. Available online: https://www.energyplus.net/weather (accessed on 21 July 2021).

38. Rotar, R.; Jurj, S.L.; Susany, R.; Opritoiu, F.; Vladutiu, M. Global energy production computation of a solar-powered smart home automation system using reliability-oriented metrics. Energies 2021, 14, 2541. [CrossRef]

39. Wang, G.; Wang, F.; Chen, Z.; Hu, P.; Cao, R. Experimental study and optical analyses of a multi-segment plate (MSP) concentrator for solar concentration photovoltaic (CPV) system. Renew. Energy 2019, 134, 284-291. [CrossRef] 
40. Asaee, S.R.; Nikoofard, S.; Ugursal, V.I.; Beausoleil-Morrison, I. Techno-economic assessment of photovoltaic (PV) and building integrated photovoltaic/thermal (BIPV/T) system retrofits in the Canadian housing stock. Energy Build. 2017, 152, 667-679. [CrossRef]

41. Heim, D. The simultaneous effect of the operating temperature and solar radiation on the efficiency of photovoltaic panels. Arch. Civ. Eng. 2011, 57, 261-274. [CrossRef] 